\title{
The Rise of a Pandemic-related Writing Style in the News Media
}

\section{Afiqah Mior Kamarulbaid, Wan Anita Wan Abas, Siti Zobidah Omar \& Rosmiza Bidin}

To Link this Article: http://dx.doi.org/10.6007/IJARBSS/v11-i10/11485

DOI:10.6007/IJARBSS/v11-i10/11485

Received: 10 August 2021, Revised: 15 September 2021, Accepted: 30 September 2021

Published Online: 19 October 2021

In-Text Citation: (Kamarulbaid et al., 2021)

To Cite this Article: Kamarulbaid, A. M., Abas, W. A. W., Omar, S. Z., \& Bidin, R. (2021). The Rise of a Pandemicrelated Writing Style in the News Media. International Journal of Academic Research in Business and Social Sciences, 11(10), 1053-1063.

\section{Copyright: (c) 2021 The Author(s)}

Published by Human Resource Management Academic Research Society (www.hrmars.com)

This article is published under the Creative Commons Attribution (CC BY 4.0) license. Anyone may reproduce, distribute, translate and create derivative works of this article (for both commercial and non-commercial purposes), subject to full attribution to the original publication and authors. The full terms of this license may be seen at: http://creativecommons.org/licences/by/4.0/legalcode

Vol. 11, No. 10, 2021, Pg. $1053-1063$

Full Terms \& Conditions of access and use can be found at http://hrmars.com/index.php/pages/detail/publication-ethics 


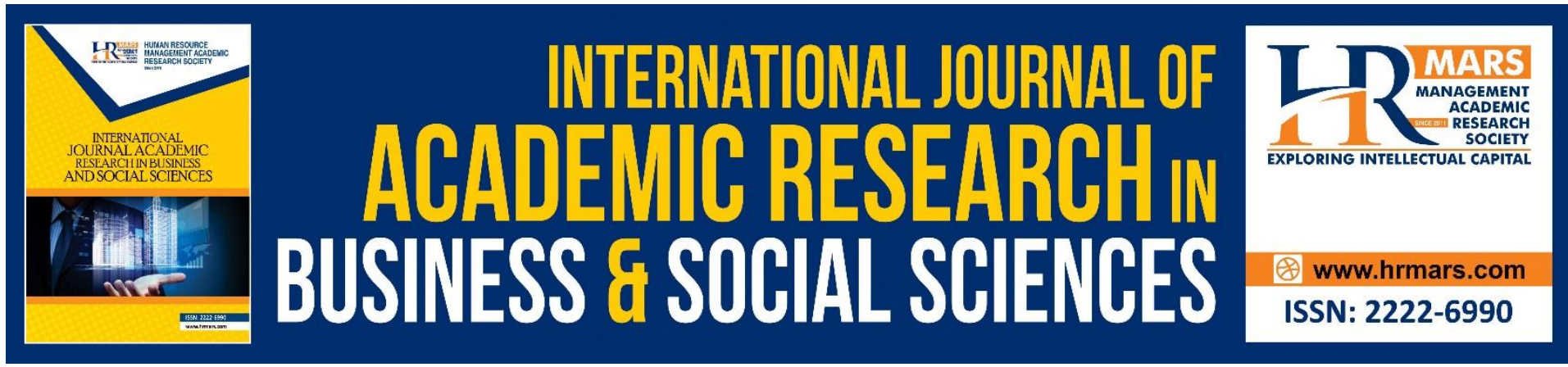

\title{
The Rise of a Pandemic-related Writing Style in the News Media
}

\author{
Afiqah Mior Kamarulbaid, Wan Anita Wan Abas, Siti Zobidah \\ Omar \& Rosmiza Bidin \\ Universiti Putra Malaysia, Malaysia
}

\begin{abstract}
This study examines journalistic writing styles in Covid 19 pandemic reporting on Malaysian online news portals through content analysis. The discussion is divided into research questions, such as (1) what is the pattern of the news writing style used in Covid 19 reporting on online news portals, (2) how Malaysia Kini and Malay Mail source and frame news on pandemic Covid 19. Content analysis were used to examine trends in the use of writing patterns. The study found that the writing patterns in covid 19 news delivery were descriptive, interpretative, and data journalism.
\end{abstract}

Keywords: News Writing Style, Descriptive, Interpretive, Infographic, Covid 19, Online News Portal.

\section{Introduction}

The journalism industry's landscape has changed dramatically, and it continues to encounter new challenges and opportunities as it progresses toward technological modernity. The journalism industry is expanding in tandem with the advancement of technology. Digital news includes the approach in which news articles are written. The style of news writing is an essential component in the field of journalism. Yang et al (2019) shows that linguistic features and news writing structure (DeAngelo \& Yegiyan, 2019) significantly impact news quality.

The internet and technology have changed the form of news writing in digital news portals. According to Greenberg (2016), adding specialist skills in text selection and structuring helps create consistency of voice in online news writing. Furthermore, the news writing style in online news welcomes new approaches to the journalistic narrative by employing digital resources to animate literary journalism techniques (Jacobson, Marino \& Gutsche, 2016). The advent of digital journalism has impacted news writing, specifically journalists' ability to engage and communicate with the audience (Haugaard, 2018).

Soares (2020) defines news writing as raising awareness and identifying "unidentified story elements" (Willman, 2020). In addition, the news writing style in online news provides a civic role by informing and enlightening society (Hassan, 2020). Thus, understanding the news writing style is critical because it enables new chances by leveraging the internet, its platforms, and its capacity to create different types of news writing (Maniou, Stark \& Touwen, 2020). 
Digital news demonstrates that digital journalism, or online information, has emerged as a significant and rising news source. The way report is created and represented has also evolved. The growth of the internet has also impacted how information and news about coronavirus disease are disseminated (Covid-19). Covid -19 has gained a great deal of attention on online news sites.

The style of news writing used in communicating Covid-19 news to the public is essential. Thus, news writing patterns have been influenced by digital communication, particularly the rising interconnection between verbal output and images (Facchinetti, 2021) and their choice of article angle, tone, and point of view (Pauly, 2014).

The pattern of reporting about the Covid-19 pandemic is significant in transmitting information or news to the audience. According to Knight (2015), the value of visual appeals, such as infographics, charts, stats maps, graphs, number pull quotes, or tables, is greater than that of any other kind of journalism. The development of news writing style because the effect of news portals is a result of information overload (Oh et al., 2021; Chen \& Masullo Chen, 2020), which has resulted in increasingly urgent demands for news literacy on "fake news," misinformation, and disinformation (Johnson et al., 2021).

The researcher's goal in conducting this study was to:

(a) explore the style of news writing in Malaysia's digital news portal by identifying the patterns used by journalists when delivering Covid 19 news online.

(b) this study aims to explore how differently Malaysia Kini and Malay Mail frame news writing on pandemic covid 19.

\section{Background of News Writing Style in Malaysia}

News writing style includes the form, organisation, and norms of journalistic writing (JohnsonCartee, 2005). Initially published in Penang in 1805, the Prince of Wales Island Gazette was Malaya's first newspaper (as Malaysia was known before 1965). Other newspapers followed, including The Malacca Observer, The Perak Pinoor, and The Malaya Mail. Commercial news and advertisement made up a sizable portion of the newspaper content (Yusoff et al., 2006).

As a result of the rise of social media, the pattern of news writing is transforming. An analysis of data by year revealed that journalists used a descriptive writing pattern in 1987, according to Zuwairi et al. (2016). No proof exists that journalists use interpretive components while conveying specific news articles. "In 1997, Utusan Malaysia journalists utilised a mixed (descriptive and interpretive) writing pattern at a rate of 6.2 per cent, which grew to 8.8 per cent in 2014." In contrast to Berita Harian, the percentage of people who employ mixed writing styles was 3.8 per cent in 1997 and 16.2 per cent in 2014. Berita Harian has grown significantly." (p. 311)

The development of news writing demonstrates that journalists employed a diverse writing pattern to cover news between 1997 and 2014. Furthermore, according to Zuwairi and Normah (2017), "two (2) elements influence the changes in writing styles that occur in Malaysia as technology advances: internal factors and external factors." (p.455).

\section{Inverted Pyramid Versus Narrative News Style of Writing in Online Journalism}

The inverted pyramid news writing style is referred to as "simple uncomplicated style" (Kerrick, 1959), it is seen as an essential part of objectivity (Thomson et al., 2008) in news reporting, and it emphasises the importance of news (Harcup \& O'Neill, 2016; Jorge, 2008). 
The inverted pyramid news writing style is intended to improve the quality of news communication (Pottker, 2003). The inverted pyramid style pattern begins with a lead sentence that includes the five Ws (who, what, when, where, and why) of the topic events as well as the $H$ (how) (Ryan \& Tankard, 1977).

Several types of research have been conducted to understand better the consumers of the inverted news writing style in news reporting. Norambuena, Horning, and Mitra (2020) investigated the structural differences between breaking and non-breaking news by evaluating how well a news article complies with the pyramid structure format. Furthermore, Rafiee et al. (2018) study if the textual organisation of news texts varies across cultural contexts. While Zuwairi et al (2016) conducted an inverted pyramid study, concentrating on the reporter writing from information delivery, specifically in election news. Previous research indicates that descriptive writing is commonly employed in political news reporting (Olsson \& Nord, 2015; Zuwairi et al., 2016).

The phenomenon of evolving writing patterns began to change. Because of the advancement of digital technologies, the news writing style has transformed from being primarily descriptive (inverted pyramid) to becoming more interpretive (narrative) (Soontjens, 2019). As "objectified journalism" became the standard in the American newsroom at the beginning of the twentieth century, the narrative style was regarded as more subjective and novelistic (Hartsock, 1998). Even in the United States, research, notably on political news, has revealed that interpretive journalism (i.e., trivia, entertainment, and opinions) has served as a substitute for reporting and has shifted toward personal and literary forms (Houston, 2008). The use of interpretive journalism in today's news has gradually increased (Soontjens, 2019).

Writing news in the form of an inverted pyramid increases the communicative quality of a journalistic product by presenting the most critical information at the top and making it easy for readers to recognise what type of information reporters want to give (Po ttker, 2013). (Stuart, 2017; Zhang et al., 2014). Furthermore, by employing an inverted pyramid style, the audience spends less time reading stories while remembering them more than narrative stories (DeAngelo \& Yegiyan, 2018). Social media news, in particular, is quick, simple, and viral (Farmer, 2012). However, while presenting the narrative style of online news writing as storytelling, Bird (1998) emphasised a danger of narrative writing replacing rational, analytical, and critical analysis in the news.

\section{Reporting on the Covid-19 outbreak}

Information about the Corona Covid-19 epidemic was widely covered in online media, especially news portals, from early 2020 until today. The global and extensive coverage of the Corona COVID-19 epidemic includes content, news consumer behaviour, and news production.

How drew researchers examining the Corona Virus in the news to Covid 19 reportage in online media. According to prior research, news studies on Covid 19 include a wide range of topics, including fake news in reporting (Yang et al., 2021; ang \& Tian, 2021; Shrivastava et al., 2020) and disinformation (Caldarelli et al., 2021; Shim, Lee \& Ahn, 2021). Based on the current findings, the study of Covid 19 reporting on online media focuses on reporting ethics. 
The covid 19 reporting study also looks at content, audiences, platforms, and production techniques (Ceide, López, \& Ivarez, 2020). Furthermore, recent research has found Covid 19 reporting to be highlighted in studies on the role of news impact on news consumers (Hoewe, Brownell \& Wiemer, 2021). Aside from that, the COVID-19 news reporting study discusses the issue of comparative analysis of online news content objectivity (Pristianita et al., 2021).

In disseminating information and news, news writing plays a crucial role in understanding news content. Li's (2021) research focuses on the text on the web-based on the covid 19 news data. At the same time, the study focused on employing a semantic knowledge network to model, structure, and store COVID-related news stories (Al-Obeidat et al., 2021). Furthermore, Papa and Maniou (2020) examine the role of narrative news style in researching the constructed meanings associated with this issue and interpreting users' perception of news content uploaded on social networks in understanding news writing in covid-related news 19.

This study fills a journalistic gap on Covid 19 in the age of digital journalism. There is a lack of research on news writing and reporting on online news portals, notably in Malaysia.

\section{Methodology}

The researchers conducted a quantitative content analysis in which the data were descriptively presented. One hundred eighty units of analysis were subjected to content analysis, focusing on Covid 19 news in Malaysia. The study examined articles from Malaysia Kini and Malay Mail online news portals from July 19 to July 23, 2021. The researchers chose Malaysia Kini and Malay Mail because these two online news portals are among Malaysia's Top 30 news portals that readers prefer.

\section{Findings}

\section{News writing style}

Table 1 shows the overall frequency of news writing patterns in Covid 19 news. There were 118 descriptive news stories, 50 interpretive descriptive writing patterns, and 13 items of data journalism news style of writing

Table 1. The total frequency of overall news writing patterns.

\begin{tabular}{lll}
\hline News writing style & Frequency & Percentage \\
\hline Descriptive & 118 & 65.5 \\
\hline Interpretive journalism & 50 & 27.7 \\
\hline $\begin{array}{l}\text { Data } \\
\text { (infographic/ video) }\end{array}$ & 13 & 7.2 \\
\hline Total & 180 & 100 \\
\hline
\end{tabular}

The study's findings reveal three types of news writing styles Malaysia Kini and Malay Mail employed in their coverage of Covid 19 on the online news portal. The graphic method and visualisation components are used to explain the data journalism writing pattern.

The use of data journalism in reporting Covid 19 on the online news site helps readers understand how the data is acquired, why the information is relevant, and what the data signify to the individuals they represent. McBride (McBride, 2020). The data journalism 
writing style is likewise tied to interaction time, and visual narratives can reflect role conformity and conflict in ways that verbal narratives cannot (Thomson, 2018).

Table 2 shows the frequency values of writing pattern components found in Malaysia Kini and Malay Mail news portals. According to the statistics, the frequency of elements in news writing style in Covid 19 reporting indicates the descriptive characteristic of news writing style with 92 Malaysia Kini and Malay Mail 26 articles. Malay Mail has 24 pieces in its interpretive news writing style, whilst Malaysia Kini has 36 . The last news writing style selected by journalists is data journalism. Malaysia Kini uses five articles of news writing style data, while Malay Mail uses eight pieces.

Comparative of Malaysia Kini and Malay Mail

Table 2. The contrast in the writing style between the news portal news Covid $\mathbf{- 1 9}$

\begin{tabular}{lll}
\hline News writing style & Malaysia Kini & MalayMail \\
\hline Descriptive & 92 & 26 \\
\hline Interpretive & 36 & 14 \\
\hline $\begin{array}{l}\text { Data Journalism } \\
\text { (infographic/ video) }\end{array}$ & 5 & 8 \\
\hline Total & 133 & 48
\end{tabular}

The total frequency between Malaysia Kini and Malay Mail did not differ considerably based on the descriptive findings. According to the study results, the descriptive news writing style is frequently utilised in reporting on Covid 19 on online news portals. Meanwhile, both platforms disseminate the news through journalism data writing.

Data from a content analysis study revealed improvements in writing patterns in reporting on online news portals. Journalists present information using the data writing pattern of journalism. According to content analysis quantitative, journalists are starting to choose writing patterns on whether they want to provide information in descriptive, interpretative, or data journalism form of news writing.

\section{Discussion and Conclusion}

The news writing pattern investigated is journalistic news writing in descriptive, interpretative, or data journalism writing patterns during a specific timeframe. Overall, the content analysis method discovered that the writing pattern in Covid 19 news maintained descriptive use and improved news representation by employing data journalism with video and graphical representation. Improvements in news writing style have been observed since 1997, since the emergence of technology, particularly the Internet in Malaysia (Zuwairi et al., 2016).

Journalists use descriptive news writing style to present news about the Covid Pandemic -19 because descriptive news writing style focuses on what, when, where, and who, as well as verified facts (Salgado and Strömbäck, 2012). Aside from that, Covid 19 reporting is breaking news. According to Norambuena, Horning, and Mitra (2020), breaking news reporting is more appropriate to employ descriptive or inverted pyramid news styles in reporting.

The Pandemic Covid 19 news also provided a new style to the news. Covid 19 news is presented in descriptive or interpretative news writing style and data journalism with 
infographics and visualisation. According to Lu. et al (2020), the news writing style's development towards data journalism offers significantly more information. Since the development of the news writing style in digital journalism promotes interaction, hypertextuality, and multimedia (Palau-Sampio and Sánchez-Garca, 2020). Finding demonstrates that data journalism of news writing style can provide the reader with a more engaging visual than just the facts.

The news writing style of Pandemic has developed. When data journalism is combined with engaging headlines, visual news, and unique graphic representation, news reporting can benefit from a massive network of traffic that can be utilised to send information to readers while also attracting clickbait in digital media. Furthermore, prior research has indicated that interactivity encourages the audience to become more engaged in their news consuming experiences (Chung \& Nah, 2009). Moreover, the study's findings regarding the evolution of this writing pattern are consistent with DeAngelo and Yegiyan (2019). They demonstrated that the development of news writing in online news portals influences both reading time and memory.

As indicated by the study's findings, both news portals prefer to employ descriptive news writing style in reporting Covid 19 since it allows journalists to avoid misinformation or misinterpretation and the spread of fake news. Descriptive or inverted pyramid news writing style is known as "basic straightforward style" (Kerrick, 1959), and it is regarded as an essential element of objectivity (Thomson et al., 2008) in news reporting, emphasising the importance of the news (Harcup \& O'Neill, 2016; Jorge, 2008). The inverted pyramid news writing style is used to increase the quality of news communication (Pottker, 2003).

Finally, the development of news writing style during the epidemic Covid 19 contributes to the consistency and diversity of news reporting in the digital news portal. The study's findings highlighted the necessity of media literacy among readers, particularly those who utilise digital media such as social media and news portals.

A study of the development of news writing style opens up new perspectives on journalism. If, in the past, writing centred on lengthy news writing styles, the news writing style has evolved in digital journalism. The development of the news writing style in reporting epidemic Covid-19 involves refining news stories by gathering, organising, evaluating, writing, and visualising data. Also of note, while the development of news writing style can assist journalists in providing the analysis and insight required to make sense of the key themes on Covid 19 through applying the data journalism pattern. It can give people the impression that the news media does not provide the facts on their own.

Many aspects of research on news writing style in Malaysia remain to be investigated, such as the advancement of news writing style in Malaysian media organisations and the suggestion of acceptable and practical models for incorporating news writing style into academic education.

Furthermore, more in-depth research of the ethical practice of news writing style in digital news portals is required. Readers are concerned about the credibility of their information sources as the news writing style evolves. It is crucial to investigate the audience's reaction to 
news writing style. As a result, the study's findings should be interpreted and generalised, considering the chosen news writing style and target audience.

\section{Acknowledgement}

Foremost, I would like to express my sincere gratitude to my advisor Dr. Wan Anita Wan Abas, for my PhD study and research's continuous support and her patience, motivation, enthusiasm, and immersion knowledge. Her guidance helped me in all time of research and writing of this paper.

Besides my advisor, I would like to thank the rest of my co-supervisors: Associate Professor. Dr Siti Zobidah Omar and Dr Rosmiza Bidin, for their encouragement, insightful comments and complex questions.

My most profound appreciation belongs to my family for their patience and understanding. Without their love and support over the years, none of this would be possible. They have always been there for me, and I am thankful for everything they have helped me achieve.

\section{Corresponding Author}

Wan Anita Wan Abas

Universiti Putra Malaysia, Malaysia

Email: anita@upm.edu.my

\section{References}

\section{Journal article}

Al-Obeidat, F., Adedugbe, O., Hani, A. B., Benkhelifa, E., \& Majdalawieh, M. (2020). Cone-KG: A semantic knowledge graph with news content and social context for studying covid19 news articles on social media. Paper presented at the 2020 7th International Conference on Social Network Analysis, Management and Security, SNAMS 2020, doi:10.1109/SNAMS52053.2020.9336541

Bird, S. E. (1998). News We Can Use: An Audience Perspective on the Tabloidisation of News in the United States. Javnost - The Public, 5(3), 33-49. doi:10.1080/13183222.1998.11008681

Caldarelli, G., De Nicola, R., Petrocchi, M., Pratelli, M., \& Saracco, F. (2021). Flow of online misinformation during the peak of the COVID-19 pandemic in italy. EPJ Data Science, 10(1) doi:10.1140/epjds/s13688-021-00289-4

Ceide, C. F., López, M. T., \& Álvarez, M. V. (2020). Impact of the COVID-19 on television in spain: Content, audience, platforms and production strategies. [Impacto del COVID-19 en la televisión en España: Contenidos, audiencias, soportes y estrategias de producción] RISTI - Revista Iberica De Sistemas e Tecnologias De Informacao, 2020(E35), 572-585.

Chung, D. S., \& Nah, S. (2009). The Effects of Interactive News Presentation on Perceived User Satisfaction of Online Community Newspapers. Journal of Computer-Mediated Communication, 14(4), 855-874. doi:10.1111/j.1083-6101.2009.01473.x

DeAngelo, T. I., \& Yegiyan, N. S. (2019). Looking for efficiency: How online news structure and emotional tone influence processing time and memory. Journalism and Mass Communication Quarterly, 96(2), 385-405. doi:10.1177/1077699018792272 
Facchinetti, R. (2021). News discourse and the dissemination of knowledge and perspective: From print and monomodal to digital and multisemiotic. Journal of Pragmatics, 175, 195-206. doi:10.1016/j.pragma.2021.01.015

Farmer, W. (2012). The Effect of Facebook on Parasocial Interaction in Local News, 11(June), 29-49. Retrieved from http://scholar.lib.vt.edu/theses/available/etd-05112012155334/

Greenberg, S. L. (2016). Editing, fast and slow. Journalism Practice, 10(4), 555-567. doi:10.1080/17512786.2015.1114898

Hassan, R. (2020). Digitality, virtual reality and the 'Empathy machine'. Digital Journalism, 8(2), 195-212. doi:10.1080/21670811.2018.1517604

Harcup, T., \& O'Neill, D. (2016). What is news?: News values revisited (again). Journalism Studies, 1-19. https://doi.org/10.1080/1461670X.2016.1150193

Haugaard, R. H. (2018). Journalistic news writing: A case study on revisions of content and form. Fachsprache, 40(3-4), 122-140. doi:10.24989/fs.v50i3-4.1517

Hoewe, J., Brownell, K. C., \& Wiemer, E. C. (2021). The role and impact of fox news. Forum (Germany), 18(3), 367-388. doi:10.1515/for-2020-2014

Houston, B. (2008). Interpretive Journalism. The International Encyclopedia of Communication.doi:10.1002/9781405186407.wbieci081

Jacobson, S., Marino, J., \& Gutsche, R. E. (2016). The digital animation of literary journalism. Journalism, 17(4), 527-546. doi:10.1177/1464884914568079

Johnson, N. R., Paal, K., Waggoner, E., \& Bleier, K. (2021). Scales for assessing news literacy education in the digital era. Journalism and Mass Communication Educator, 76(2), 156175. doi:10.1177/1077695820930980

Jorge, T. de M. (2008). News values in news websites: An empirical study of the criteria of newsworthiness in Argentina and Brazil. Brazilian Journalism Research, 4(1), 53-71. Retrieved from http://bjr.sbpjor.org.br/bjr/article/view/135

Kerrick, J. S. (1959). The Inverted Pyramid Style and Attitude Change. Journalism \& Mass Communication Quarterly, 36(4), 479-482. doi:10.1177/107769905903600412

Knight, M. (2015). Data journalism in the UK: A preliminary analysis of form and content. Journal of Media Practice, 16(1), 55-72.

https://doi.org/10.1080/14682753.2015.1015801

Krueger, C. C., \& Swatman, P. M. C. (2005). The Impact of Internet Technology on the Online Content Sector: Value Webs in online news and music. Citeseer, 1-12. Retrieved from http://citeseerx.ist.psu.edu/viewdoc/download?doi=10.1.1.63.5142\&rep=rep1\&type= pdf

Li, T., Fang, L., Lou, J., Li, Z., \& Zhang, D. (2021). AnaSearch: Extract, retrieve and visualize structured results from unstructured text for analytical queries. Paper presented at the WSDM 2021 - Proceedings of the 14th ACM International Conference on Web Search and Data Mining, 906-909. doi:10.1145/3437963.3441694

Lu, D., Whitehead, S., Huang, L., Ji, H., \& Chang, S. (2020). Entity-aware image caption generation. Paper presented at the Proceedings of the 2018 Conference on Empirical Methods in Natural Language Processing, EMNLP 2018, 4013-4023. Retrieved from www.scopus.com

Maniou, T. A., Stark, A., \& Touwen, C. J. (2020). Journalism training beyond journalism schools. Journalism and Mass Communication Educator, 75(1), 33-39. doi:10.1177/1077695820904979 
Chen, M. G., Ng, Y. M. M., Riedl, M. J., \& Chen, V. Y. (2020). Exploring how online political quizzes boost interest in politics, political news, and political engagement. Journal of $\begin{array}{llll}\text { Information Technology and } & \text { 33-47. }\end{array}$ doi:10.1080/19331681.2019.1680475

McBride, R. (2020). The stories behind the data. Significancemagazine.com, 17(2), 10-11. https://doi.org/10.1111/1740-9713.01370

Norambuena, B. K., Horning, M. A., \& Mitra, T. (2020). Evaluating the Inverted Pyramid Structure through Automatic 5W1H Extraction and Summarization. In Proceedings of Computation + Journalism Symposium (C+J 2020). ACM, New York, NY, USA, 7

Oh, H. J., Lor, Z., \& Choi, J. (2021). News repertoires and political information efficacy: Focusing on the mediating role of perceived news overload. SAGE Open, 11(1) doi:10.1177/2158244020988685

Olsson, E.-K., Nord, L. W., \& Falkheimer, J. (2015). Media Coverage Crisis Exploitation Characteristics: A Case Comparison Study. Journal of Public Relations Research, 27(2), 158-174. doi:10.1080/1062726x.2014.976827

Papa, V., \& Maniou, T. A. (2020). Recurrent narratives around the COVID-19 crisis in social networks: A case study analysis on facebook. Tripodos, 2(47), 11-28.

Pauly, J. J. (2014). The New Journalism and the struggle for interpretation. Journalism: Theory, Practice \& Criticism, 15(5), 589-604. doi:10.1177/1464884914529208

Po"ttker, H. (2003). News and its communicative quality: the inverted pyramid-when and why did it appear? Journalism Studies, 4(4), 501-511. https://doi.org/10.1080/1461670032000136596

Salgado, S., \& Strömbäck, J. (2012). Interpretive journalism: A review of concepts, operationalizations and key findings. Journalism, 13(2), 144-161. https://doi.org/10.1177/1464884911427797

Shrivastava, G., Kumar, P., Ojha, R. P., Srivastava, P. K., Mohan, S., \& Srivastava, G. (2020). Defensive modeling of fake news through online social networks. IEEE Transactions on Computational Social Systems, 7(5), 1159-1167. doi:10.1109/TCSS.2020.3014135

Soares, I. (2020). A vision of empire: Irish home rule, the scramble for africa, and portuguese literary journalism. Literary Journalism Studies, 12(1), 82-109.

Soontjens, K. (2019). The Rise of Interpretive Journalism: Belgian newspaper coverage, 19852014. Journalism Studies, 20(7), 952-971.

https://doi.org/10.1080/1461670X.2018.1467783

Stuart, A. (2017). Photojournalism and citizen journalism: co-operation, collaboration and connectivity.London and New York: Routledge.

Thomson, E. A., White, P. R. R., \& Kitley, P. (2008). Objectivity" and "hard news" reporting across cultures: Comparing the news report in english, french, japanese and indonesian journalism. Journalism Studies, 9(2), 212-228. https://doi.org/10.1080/14616700701848261

Thomson, T. J. (2018). The Evolution of Story: How Time and Modality Affect Visual and Verbal Narratives. Visual Communication Quarterly, 25(4), 199210.doi:10.1080/15551393.2018.1498742

Yang, Y., Cao, J., Lu, M., Li, J., \& Lin, C.-W. (2019). How to Write High-quality News on Social Network? Predicting News Quality by Mining Writing Style. Computation and Language. Retrieved from http://arxiv.org/abs/1902.00750 
Yang, J., \& Tian, Y. (2021). "Others are more vulnerable to fake news than I am": Third-person effect of COVID-19 fake news on social media users. Computers in Human Behavior, 125 doi:10.1016/j.chb.2021.106950

Yang, C., Zhou, X., \& Zafarani, R. (2021). CHECKED: Chinese COVID-19 fake news dataset. Social Network Analysis and Mining, 11(1) doi:10.1007/s13278-021-00766-8

Zhang, X., Pan, Y., \& Zhang, M. (2014). Superstructure Analysis in News Stories-A Contrastive Study of Superstructure in VOA, BBC, and NPR News. Asian Social Science, 10(22), 199209. https://doi.org/10.5539/ass.v10n22p199

Zuwairi, M., Saad, M., Normah, M., Ahmad, A. L., \& Hassan, B. (2016). Transformasi corak penulisan berita dalam akhbar arus perdana malaysia (Transformation of News Writing Patterns in Malaysia Mainstream Newspapers). E-Bangi, 11(1).

Zuwairi, M., Saad, M., \& Normah, M. (2017). Technology Propellant for the Transformation of Election News Writing Patterns in Malaysia. Journal of Social Sciences and Humanities 12(3), 442-458

\section{Book}

Ryan, M., \& Tankard, J. W. (1977). Basic news reporting. Palo Alto, CA: Mayfield. 